3. Grachev, N.I. (2009) Proishozhdenie suvereniteta. Verhovnaja vlast' mirovozzrenii i praktike gosudarstvennogo stroitel'stva tradicionnogo obshhestva : monografija / Grachev N.I. - Moskva : Zercalo-M (in Russian).

4. Derzhavnij suverenitet v umovah €vropejs'koï integraciï : monografija I Ju. P. Bitjak, I.V. Jakovjuk, S. G. Ser'ogina ta in. ; za red. Ju. P. Bitjaka, I. V. Jakovjuka. - K. : Red. zhurn. "Pravo Ukraïni", 2012 (in Ukrainian).

5. Laski, G. Dzh (2020) O suverenitete gosudarstva [On the Sovereignty of the State] // Vestnik Moskovskogo gosudarstvennogo oblastnogo universiteta. Serija: Istorija i politicheskie nauki. (4). [Bulletin of the Moscow Regional State University. Series: History and Political Sciences], (4) 2020, 152-161 (in Russian).

6. Koreckaja, M. A. (2019) Narod kak nositel' suverennosti i granicy politicheskoj teologii// Sociodinamika. - No 1. - S. 10-19 (in Russian).

7. Shmitt, K. (2000) Politicheskaja teologija. M. (in Russian).
8. Agamben Dzh. (2011) Homo sacer: chrezvychajnoe polozhenie Per s it. M. Velizheva, I. Levinoj, O. Dubickoj, P. Sokolova pod. red. L. Voropaj. M.: Evropa (in Russian).

9. Agamben D. (2011) Homo sacer. Suverennaja vlast' i golaja zhizn'. Moskva, Evropa (in Russian) Vkaz. tv.

0. Agamben Dzh. (2011) Homo sacer: chrezvychajnoe polozhenie.

11. Lomako L.L., Mal'cev K.G., Mal'ceva A.V. (2020) Normalizacija nasilija: strategija bezopasnosti i sovremennaja forma "politicheskogo". Gumanitarnyj vestnik, (6). [Normalizing violence: a security strategy and a contemporary form of the "political"], (6) (in Russian).

Received: $27 / 07 / 2021$

$1^{\text {st }}$ Revision: $05 / 08 / 2021$

Accepted: $20 / 09 / 2021$

D. Sevriukov, Dr. Sc. (Law), Prof.

Taras Shevchenko National University of Kyiv, Kyiv, Ukraine

\title{
THE PROSPECTS OF THE SOVEREIGNTY OF THE STATE IN THE POSTPANDEMIC WORLD
}

The article is dedicated to the study of the features of the trajectory of changes of sovereignty of the State under current crisis conditions caused by the pandemic COVID19, which shape its future prospects. The research paradigms of biopower (M. Foucault), state of emergency (K. Schmitt, J. Agamben) are used in the work, allowing not to limit the subject of study to legal positivist forms and focuses on interdisciplinary scientific research.

The processes of globalization, which led to increased interdependence between countries, the opening of borders, integration and competition of markets, capital mobility, contributed to the actualization of discourses on "erosion" and even "loss" of State sovereignty. Regional European integration also puts pressure on the sovereignty of Member States. However, the transfer some of the power to supranational structures is not a renunciation of sovereignty, but an act of sovereign self-restraint. The redistribution of authority is carried out through coordinated decisions, that correspond to the basic idea of integration, and is used primarily to optimize the implementation of public functions, to achieve a certain quality status sufficient to accoplish social goals.

With the onset of the pandemic crisis, the relative openness and transparency of the globalized and integrated world face a new reality, that strengthens the sovereignty of regulatory decisions of public authorities on the governance of people and territory. If public health in the long-term state of emergency remains a priority for the state, the consequences of the "new normality" may be the devaluation of the rule of law, which originally aims at protecting individual rights and freedoms, replacing established rules with temporary regulations. Extreme necessity justifies the use of disciplinary coercive measures, increased control over the population, the introduction of restrictions and other innovations. The combination of emergency security and state biopolitics legitimizes the priority of public interests over private ones and the use of exceptional sovereign solutions to overcome threats. Emergency governance shapes management technology, which has legal forms but can mimic law in the context of its idea.

The growth of authoritarian tendencies in public administration, legal guarantees and protection of human rights, freedoms, fundamental democratic principles, the relationship between freedom and security determine the prospects for further research.

Keywords: state of emergency, sovereign decision, biopower, pandemic, rule of law, balance of interests.

Bulletin of Taras Shevchenko National University of Kyiv. Legal Studies, 2021; 4 (119): 91-96

УДК 364.2

DOI: https:doi.org/10.17721/1728-2195/2021/4.119-18
ISSN 1728-2195

(C) Taras Shevchenko National University of Kyiv, Publishing center "Kyiv University", 2021

Л. М. Сіньова, канд. юрид. наук, доц. ORCID ID: 0000-0002-5514-3549

Київський національний університет імені Тараса Шевченка, Київ, Україна

\section{ЗАПОЧАТКУВАННЯ ТА РОЗВИТОК СОЦІАЛЬНОÏ РОБОТИ В НІМЕЧЧИНІ}

Досліджено особливості історичного розвитку соціальної роботи в Німеччині. У XIX cm. здоров'я громадян Німеччини більше розглядалося як суспільна цінність. До середини XX cm. у Німеччині поширено англо-американські методи соціальної роботи, що і нині вважають класичними. Більшість шкіл соціальної роботи були засновані церквою та відводили жінкам чітко визначену місію в межах ідеологічних і соціальних цілей, оскільки жінки розглядалися як природне і традиційне втілення благодійності. У 1970-х рр. відбулося переосмислення соціальної роботи в Німеччині через те, що вчені та практики дійшли висновку про недостатність використання класичних методів соціальної роботи, а також про незначне використання терапевтичних засобів у тuх випадках, коли йшлося про охоплення і розв'язання проблеми загалом. У науковому світі Німеччини відбувалися дискусії про користь системних підходів у соціальній роботі.

На сьогодні місія соціальної роботи - це надавати можливість людям максимально розвивати власний потенціал, збагачувати своє життя та попереджувати виникнення дисфункцій. Професійна соціальна робота спрямована на захист людини, розв'язання їі проблем і соціальні перетворення у суспільстві.

Досліджено розвиток соціальної педагогіки як науки та самостійної галузі знань і практичної діяльності соціальної роботи в Німеччині. Таким чином, для успішного розвитку в Україні системи професійної підготовки соціальних працівників із соціального захисту прав молодим фахівцям необхідно досліджувати та використовувати міжнародний досвід. Запровадження німецького досвіду в систему професійної підготовки соціальних педагогів Украӥни сприятиме задоволенню потреби держави у висококваліфікованих мотивованих фахівцях.

Ключові слова: бідність, благодійність, життєві обставини, соціальне забезпечення, соціальний працівник, соціальний педагог, соціальна допомога, соціальні послуги.

\section{ВСТУП}

В Україні та в усьому світі через пандемію зросла кількість людей, яким потрібна допомога соціальних робітників, тому затребуваність зростає з кожним днем, але, чи буде ця робота престижною в майбутньому, покаже час, оскільки заробітна плата в Україні таких працівників $€$ однією з найменших. Тому держава має звернути увагу на цю сферу [1, с. 72]. Особливо цікавим і актуальним для України є досвід Німеччини у підготовці фахівців соціальної та соціально-педагогічної робо-

${ }^{7}$ Наукове дослідження проведено в межах держбюджетної теми НДР № 20БФ042-01 "Правове забезпечення соціальної безпеки в євроінтеграційних умовах". 
ти. Саме у Німеччині гармонійно поєднується функціонування двох фрахівців - соціального педагога та соціального працівника. Вони взаємно доповнюють один одного, без утворення конкуренції розв'язують завдання соціально-педагогічної діяльності. Існує програма "Sozial wesen", яка об'єднує елементи як соціальної роботи, так і соціальної педагогіки. Тобто в цій країні збережено інститут соціальної педагогіки, як науки та спеціальності, що потрібно врахувати в системі професійної підготовки соціальних педагогів в Україні [2, с. 385].

\section{ВИКЛАД ОСНОВНОГО МАТЕРІАЛУ}

1853 р. в Еберфельді розроблено скоординовану, ефективну систему розподілу пожертвувань. Місто було поділене на райони або квартали, де призначили відповідального $з$ добровольців, чиє "робоче навантаження" становило до чотирьох родин. Ці добровольці приймали заявки на допомогу і брали на себе функцію ретельного оцінювання особистих обставин заявників відповідно до положення, розробленого міською адміністрацією [3, с. 374]. I3 середини XIX ст. в Німеччині були створені головні об'єднання, які визначають структури вільної благодійної допомоги й нині. До них належать Благодійна справа німецької євангельської церкви, Німецьке благодійне об'єднання (католицька церква), Головний благодійний центр євреїв у Німеччині, Робоча благодійність, Німецький Червоний Хрест та Німецьке паритетне об'єднання милосердя" [4, с. 34]. 1905 р. відкрилася перша християнська соціальна жіноча школа. У наступні чотири роки з'явилися ще 13 соціальних шкіл, де можна було отримати професію попечительки благодійної установи [5].

До Першої світової війни формували основу практичної соціальної роботи економіка і медицина, гігієна і психіатрія. Із заснуванням перших середніх спеціальних навчальних закладів (Fachschulen) під час війни прийшло усвідомлення того, що проблеми зі здоров'ям тісно пов'язані із соціальними проблемами, такими як: бідність, злидні, невлаштованість. Уже після 1918 р. виникли заклади для пацієнтів, що страждали різними хворобами (туберкульоз, венеричні захворювання), психічних хворих, п'яниць. У другій половині XX ст., передусім в останні його десятиліття, з'явилися поруч із відомими раніше бідністю і злиднями нові фрактори ризику - неправильне харчування або небезпечні види спорту [6, с. 34].

Слід наголосити, що індустріалізація країни спричинила різке зубожіння сімей робітничого класу, а як результат, - зросла кількість користувачів соціальних послуг. Оскільки церкви і приватні благодійні установи виявилися неспроможними впоратися із ситуацією, у другій половині XIX ст. виникла необхідність у державному регулюванні цього процесу, тобто у державному соціальному забезпеченні. 1880 р. за ініціативою Німецького конгресу 3 доброчинності створено Німецьку доброчинну спілку турботи про бідних, яку 1919 р. перейменували на Німецьку спілку державної і приватної опіки. Це центральна спілка, яка діє і нині: вона об'єднує державні, приватні, громадські установи, а також окремих фрахівців, що визначають стратегію розвитку соціальної роботи в Німеччині. 1990 р. після об'єднання НДР і ФРН кількість її учасників збільшилося до 3 тис. осіб. Держава делегувала до ї̈ складу своїх представників на фредеральному рівні, рівні федеральних земель вільних міст і округів. Важлива роль відводиться представникам громадських організацій, куди входять: Об'єднання доброчинності для робітників, католицький "Карітас", Паритетний Союз, Німецький Червоний Хрест, Союз милосердя Євангельської церкви тощо [7].

Відмінність європейської моделі на прикладі розвитку соціальної роботи у Німеччині наочно демонструє, як у діяльності кожного спеціаліста втілюється соціальна політика держави. Зволікання у розв'язанні окремих питань може призвести до соціального вибуху. Докази тому вже $\epsilon$ в історії, наприклад, із приходом фрашистів до влади і припиненням демократичного розвитку країни доброчинність була підмінена "гігієною раси", а соціальна робота була зведена до жорсткого контролю над населенням. У практиці сучасної соціальної роботи Німеччини "відчувається реальний взаємозв'язок розв'язання соціальних і економічних проблем як гарантія існування правової соціальної держави" [8, с. 120]. Отже, з початком індустріалізації в Німеччині в XIX ст. здоров'я її громадян усе більше розглядалося як суспільна цінність. А страхування і соціальна гігієна були спрямовані на його захист і підтримку. Тоді ж створено для цього правові основи у Пруссії: Закон про страхування громадян у зв'язку з хворобою (1883), Закон про страхування громадян у зв'язку з нещасним випадком (1884), Закон про страхування громадян у зв'язку з настанням похилого віку й інвалідності (1889) [6, с. 34].

Профресія соціального працівника в Німеччині виникла на початку XX ст. як суто жіноча. Перші законодавчі акти про підготовку соціальних працівників з'явилися 1918 р. У перші десятиліття соціальна допомога надавалася клієнтам тільки в критичних ситуаціях як прояв турботи. 3 розвитком законодавства із соціального забезпечення потребуючий соціальної допомоги став розглядатися як об'єкт благодійної діяльності, що надалі вплинуло на розуміння сутності професії і вибір терміна "соціальний працівник", що вже широко використовувався в інших країнах світу [9, с. 117]. У ті часи соціальна робота в Німеччині належала до кола професій, через які жінки із середнього класу отримували можливість вийти на суспільну арену, забезпечити собі вид заняття, який давав їм особисте задоволення і був соціально бажаний. Більшість шкіл соціальної роботи, заснованих церквою, відводила жінкам чітко визначену місію в межах ідеологічних і соціальних цілей, оскільки жінки розглядалися як природне і традиційне втілення благодійності. Однак були школи, створені самими жінками. У Німеччині це була широка організація "Загальнонімецька жіноча спілка", яка була заснована на жіночому конгресі 1865 р. [10, с. 73].

У 20-х рp. XX ст. благодійні союзи входили до складу Імперського Товариства основних незалежних профспілок із благодійності. Почали формуватися державні органи соціального забезпечення, що існують і в теперішній час. До перших методик соціальної роботи належить патронажний метод, що включає питання про причини виникнення проблеми. Метод заснований на принципах свідомої участі клієнтів у розв'язанні проблеми, їхній активності, принципі поваги до людської гідності, відповідальності перед суспільством, усвідомлення соціальним працівником своїх слабких і сильних сторін. У роки правління Гітлера соціальна робота стала одним зі знарядь нацистів і звелася до жорсткого контролю над населенням. Відродження демократичних норм соціального життя почалося після повалення фрашизму [5]. Слід наголосити, що до середини XX ст. У Німеччині одержали поширення англо-американські методи соціальної роботи, що сьогодні вважаються класичними. До них відносять: індивідуальну допомогу, групову терапію і роботу в громаді. Розвиток власне німецьких досліджень у сфері теорії і практики соціальної роботи в цей період ще відставало від розвитку експериментальних досліджень в інших країнах (США, Голландії, Швейцарії) [11].

Соціальна робота у будь-якій країні зберігає свою національну специфіку, обумовлену соціально-еконо- 
мічними та політичними умовами, історичними, духовноморальними, культурними й етичними особливостями. Сучасна система професійної підготовки соціальних педагогів в Україні характеризується бурхливими змінами, які іноді мають хаотичний, не досить виважений характер, тому доцільним є звернення до досвіду зарубіжних країн, які мають давню історію підготовки соціальних педагогів. У світі існує кілька тисяч вищих шкіл соціальної роботи та спеціалізованих фракультетів при університетах, що здійснюють підготовку професійних соціальних працівників [2, с. 385]. Однак 1970-ті стали роками переосмислення соціальної роботи в Німеччині через те, що вчені та практики дійшли висновку про недостатність використання класичних методів соціальної роботи, а також про незначне застосування терапевтичних засобів у тих випадках, коли йшлося про охоплення і розв'язання проблеми загалом. У науковому світі Німеччини відбувалися дискусії про користь системних підходів у соціальній роботі. На їхній базі було відпрацьовано основні моделі й вироблено принципи сучасного розвитку соціальної роботи на національному рівні в цій країні [12].

Соціальна робота - це мистецтво налагоджувати зв'язки між людьми, це покликання душі, яка співчуває та розділяє біль кожної обездоленої людини. Щоденно беручи на себе тяготи і труднощі людей, соціальні робітники реально сприяють стабільності нашого суспільства, відродженню в ньому духовності й людяності [13, с. 106-109]. Соціальна робота - як вид діяльності - вид профресійної діяльності, направленої на задоволення соціально гарантованих й особистісних інтересів і потреб різних груп населення, на створення умов, які допомагають відновленню або поліпшенню здатності людей до соціального функціонування [14]. Соціальна робота - унікальний вид професійної діяльності зі створення соціальних умов для поліпшення умов життя окремої особистості, підвищення добробуту населення. Місія соціальної роботи - надавати можливість людям максимально розвивати власний потенціал, збагачувати своє життя та попереджувати виникнення дисфункцій. Професійна соціальна робота спрямована на захист людини, розв'язання ії проблем і соціальні перетворення у суспільстві. Фахівці соціальної роботи, таким чином, $€$ агентами змін у суспільстві, а також у житті окремих людей, сімей і громад, є регуляторами правових, економічних взаємовідносин особистості з державою [15].

В Законі України "Про соціальну роботу із сім'ями, дітьми та молоддю" [16] від 21 червня 2001 р. № 2558-ІІІ визначено, що

соціальна робота із сім'ями, дітьми та молоддю професійна діяльність, спрямована на запобігання, мінімізацію негативних наслідків і подолання складних життєвих обставин сімей, дітей і молоді, посилення їхньої здатності до реалізації власного життєвого потенціалу;

фахівець із соціальної роботи - особа, яка має відповідну освіту та кваліфікацію, відповідає вимогам, установленим центральним органом виконавчої влади, що забезпечує формування державної політики у сфері соціального захисту населення.

У Законі України "Про соціальні послуги" [17] від 17 січня 2019 р. № 2671-VIII визначено, що соціальні послуги - дії, спрямовані на профрілактику складних життєвих обставин, подолання таких обставин або мінімізацію їхніх негативних наслідків для осіб/сімей, які в них перебувають. Особі/сім'ї можуть надаватися одна або одночасно декілька соціальних послуг. Порядок організації надання соціальних послуг затверджується Кабінетом Міністрів України.
У сучасній Німеччині замість терміна "соціальна робота" більше вживають словосполучення - "соціальна педагогіка". У німецьких колах науковців вважається недоцільним розмежовувати ці два терміни, тому їх використовують як синоніми. "Соціальною педагогікою" в Німеччині вважають сукупність усіх соціальних профресій і видів діяльності соціальних служб. Тут загальноприйнятою $є$ думка, що молодим безробітним людям, безхатченкам, або просто матеріально незабезпеченим більше потрібна матеріальна допомога, а не педагогічний вплив. 1968 р. у Німеччині для підготовки соціальних педагогів засновано університетську спеціалізацію, тому німецькі соціальні педагоги вважаються найбільш висококваліфрікованими із широким колом професійних компетенцій порівняно з підготовкою соціальних педагогів в інших країнах Європи. Крім того, німецькі роботодавці вимагають від соціальних педагогів більше додаткових спеціальних знань у галузі культури, музики та терапії. Більше затребуваними є соціальні педагоги, які готові до постійного оновлення знань і співпраці з волонтерами і працівниками державних управлінь. Зосереджується увага на рівні комунікабельності соціальних працівників, навичках групової роботи та взаємодії з клієнтами, їхньому ставленні до відповідальності, організаторських здібностей, схвалюється готовність їх до самопожертв [18].

Соціальна педагогіка - галузь педагогіки, що вивчає закономірності соціально-культурної адаптації людини, групи, суспільства з метою гармонізації, гуманізації їхніх взаємовідносин на внутрішньо-, між- та надособовому рівнях. Соціальна педагогіка $€$ галуззю педагогіки. Основна категорія, яку вона розглядає - соціалізація особистості (входження особистості в соціальне середовище, прийняття норм, цінностей і правил цього середовища). Термін "соціальна педагогіка" вперше був введений у дискусію про виховання К. Магером 1844 р. і далі поширений А. Дистервегом. 3 моменту виникнення цього поняття до теперішнього часу в німецькій науковопедагогічній літературі простежують два його різні трактування, що визначають різні підходи в розвитку цієї галузі наукового знання. Згідно з першим трактуванням, соціальна педагогіка особливо виділяє соціальну сторону у вихованні (К. Магер); згідно з другим трактуванням вона виступає як педагогічна допомога в певних соціальних умовах, ситуаціях (А. Дистервег) [19].

Соціальна робота існувала в людському суспільстві як допомога і взаємодопомога споконвіку, спираючись на загальнолюдські духовні цінності. Соціальний працівник - це посередник між суспільством, соціальною групою, сім'єю та індивідом. Соціальний працівник - це безперервна освіта і самоосвіта впродовж життя; це висока відповідальність перед суспільством за долю людей, які довірили свої проблеми, які потребують допомоги [13, с. 106-109]. Разом із розвитком соціальної педагогіки як науки в Німеччині активно розвивається сфера професійної діяльності фахівця в галузі соціальної педагогіки. 31908 р. ведеться підготовка соціальних педагогів; на початку 1970-х рр. в університетах Німеччини розпочато підготовку соціальних педагогів із вищою освітою. Слід зазначити, що в Німеччині, поряд із соціальною педагогікою, протягом XX ст. активно розвивалася як самостійна галузь знання і практичної діяльності соціальна робота. Однак оскільки професійна діяльність соціальних педагогів і соціальних працівників має багато спільного, із часом вони були об'єднані в одну професійну сферу, яка нині регулюється єдиним стандартом, де назви цих фахівців вживаються як синоніми: соціальний працівник/соціальний педагог. Вони виконують у суспільстві такі функції: виховну, інформаційну, консультативну, підтримки, допомоги, організації, 
захисту та представлення інтересів клієнта. Однак в їхній діяльності $€$ і свої відмінності. Головне полягає в тому, що традиційними адресатами соціальної педагогіки є діти і молодь; вона концентрує свою увагу на допомозі у вихованні й освіті [19].

У Федеральному Законі Німеччини про соціальне страхування від 23 березня 1994 р. міститься перелік соціальних послуг, які надаються в цій країні. Зокрема у $\S 21$ визначено, що до них належать допомога на харчування у вигляді одноразових виплат, ремонт одягу, білизни та взуття, закупівля пального для окремих опалювальних приладів, надання спеціальних освітніх ресурсів для студентів, ремонт побутових приладів, догляд за квартирою [20]. Головним завданням, окресленим у восьмій книзі Соціального Кодексу Німеччини є підтримка сучасної сім'ї у її виховних функціях, тому сприяння вихованню в сім'ї охоплює цілий спектр послуг інституту допомоги молоді, спрямованих як на батьків, так і на молодих людей, що перебувають у різних життєвих ситуаціях. До них належать: сімейна освіта (готує молодих людей до подружніх відносин і спільного життя з дітьми, до співпраці 3 дитячим садком, групою продовженого дня, соціальною сім'єю, центром матерів); консультації із загальних питань виховання та розвитку молоді; сімейне дозвілля та відпочинок (особливо у проблемних родинах, за потреби включає патронаж дітей) [21, с. 238].

Слід наголосити, що соціальна і соціально-педагогічна робота в Німеччині здійснюється на трьох рівнях: державному, регіональному та місцевому. На державному рівні реалізацією займається Міністерство соціального забезпечення, основними напрямами діяльності якого є:

- керівництво практичним і фрункціональним розвитком соціального обслуговування населення;

- визначення пріоритетних ліній у сфері соціального забезпечення;

- упровадження соціальних інновацій;

- підготовка необхідних законопроєктів і постанов;

- організація курсів підвищення кваліфікації фрахівців соціальної та соціально-педагогічної діяльності [9, с. 118].

У ФРН нині домінує думка про те, що, як із погляду профресійної діяльності, так і з теоретичної, недоцільно говорити про їхнє розмежування. У цій країні виходять із міркування, що безпритульні й бездоглядні молоді люди потребують не лише педагогічної, але й матеріальної підтримки, і навпаки - молоді безробітні або наркомани потребують не лише матеріальної допомоги, а й педагогічного впливу [22, с. 5-6].

Правові основи соціально-педагогічної роботи 3 дітьми, молоддю та сім'ями закріплено у Восьмій книзі Соціального кодексу Німеччини, в якій зафріксовано принципи, основні види і форми надання соціальнопедагогічних послуг. Серед них найбільш сімейно орієнтованими $€$ сприяння вихованню в сім'ї та допомога у вихованні. Їхнім завданням $€$ впливати на усвідомлення сім'єю її відповідальності за виховання дітей. До соціально-педагогічних послуг щодо сприяння процесу виховання в сім'ї належать: сімейна освіта, сімейне консультування, організація сімейного дозвілля і відпочинку. Допомога у вихованні передбачає кваліфіковану підтримку сімей, її окремих членів у складних життєвих ситуаціях і надається у фрормі амбулаторних (консультування з питань виховання, підтримка у вихованні, соціально-педагогічна допомога сім'ї), частково стаціонарних (виховання в денній групі або в соціальній сім'ї) та стаціонарних (влаштування дітей у прийомну сім'ю чи заклад інтернатного типу) видів допомоги. Для здійснення соціально-педагогічної допомоги сім'ї фахівці використовують різноманітні методи, сукупність яких значною мірою визначає ефективність сімейно орієнтованої діяльності [23, с. 9-10].

Основними тенденціями, які властиві адміністративно-правовому регулюванню соціального обслуговування в зарубіжних країнах, є постійне розширення спектра соціальних послуг; приділення особливої уваги соціальному обслуговуванню дітей, особливо дітей з інвалідністю та дітей, позбавлених батьківського піклування; звільнення центральних державних органів від багатьох соціальних фрункцій та їхнє перенесення на місцеві органи самоврядування; активна взаємодія з громадськими організаціями; рівний розвиток суб'єктів надання соціальних послуг різних форм власності; посилення гарантування прав громадян у сфері соціального обслуговування з боку держави, зокрема і шляхом здійснення контрольної діяльності [24, с. 114-115].

Як наголошує С. О. Кубіцький, за останні 40 років теорія і практика соціальної роботи і соціальної педагогіки в Німеччині значно розвинулися. Активізація соціально-педагогічної діяльності мотивувалася процесом удосконалення соціальної структури суспільства, що поставило перед соціальною роботою і соціальною педагогікою багато нових і складних проблем починаючи з допомоги біженцям, цілим родинам, переселеним з інших країн, літнім і мало захищеним людям, роботи в соціально-педагогічних інститутах і різних соціальних службах і аж до кооперації з громадянськими ініціативами і групами самодопомоги у соціальній роботі в даний час [9, с. 118].

Як зазначає У. Штрауб у своїй статті "Соціальна робота і зв'язки з громадськістю в Німеччині" особливе місце у підготовці соціальних працівників/соціальних педагогів займають PR-технології, тобто "паблік релейшенз технології", що позначають процес комунікації, створення соціальних зв'язків із громадськістю. Студенти навчаються використовувати різні PR-методи в соціальній роботі: флаєри, постери, готові звіти, сайти інтернету, безпосередні контакти, пресу, телебачення тощо. У. Штрауб зазначає, що це підвищує соціальний статус професії соціального педагога, привертає увагу суспільства до нерозв'язаних проблем, слугує більшій конкретизації практичних результатів соціальної роботи [25, с. 75-87].

Однією з новітніх програм, що функціонують у Німеччині, $є$ програма FSJ (Соціальний рік у Німеччині), що $\epsilon$ важливим здобутком у сфері надання соціальних послуг. Ця програма є державною і дозволяє молодим людям віком від 18 до 26 років включно впродовж року здійснювати практичну діяльність у соціальній сфері в Німеччині. Програма триває один рік і за бажанням може бути продовженою до 18 місяців. Під час своєї практики її учасники отримують фріксовану грошову винагороду, що менша ніж мінімальна заробітна плата, але дає можливість забезпечити своє перебування в Німеччині. FSJ надає можливість вивчити мову, подорожувати Німеччиною й набути професійних навичок у соціальній роботі. Крім того, одна з можливостей ії - почати нове життя, стати самостійним і незалежним. Допомога іншим - ось що робить нас соціальними людьми. Це додаткова практика для вже практикуючих соціальних працівників працювати в інших регіонах, 3 іншими людьми, їхніми проблемами. Крім того, це чудова база для вступу до університету [26]

Для успішного розвитку в Україні системи професійної підготовки соціальних працівників із соціального захисту прав молоді необхідно досліджувати міжнародний досвід, у першу чергу країн Європи, як ближчих за деякими фракторами ментальності суспільств та відповідно до державної стратегії України до Європейської інтеграції. Однак використовувати досвід країн Європи 
необхідно в системі вітчизняної вищої освіти з урахуванням політичних і соціально-економічних відмінностей, зокрема і в культурно-історичних традиціях. Ключовою метою соціального працівника має бути створення найбільшого психологічного комфорту та захисту молодої особистості, і у процесі досягнення цієї мети необхідно об'єднувати зусилля всіх фахівців соціальнопедагогічної та соціальної сфери. Результатом діяльності соціальних працівників повинна бути не тільки ефективна система соціального захисту та допомоги, але й забезпечення процесу саморозвитку особистості [18].

Для переймання та застосування зарубіжного досвіду методів соціальної роботи та соціального захисту населення соціальним працівникам в Україні, передусім необхідно вивчити зміст технологій соціальної роботи в європейських країнах, а саме: детальне вивчення стану соціально-педагогічної роботи з підтримки та захисту дітей і молоді в європейських країнах із визначенням їхніх основних аспектів; застосування європейського досвіду підготовки соціальних працівників у вітчизняній системі освіти [18].

Посол Німеччини в Україні Анка Фельдгузен зазначила, що Україна перебуває на дуже важливому етапі перебудови системи соціальних послуг і адаптації послуг до потреб мешканців громад. Від того, як місцеве самоврядування впорається із цим завданням, залежить благополуччя вразливих категорій населення і громади загалом. У цей переломний момент уряд Німеччини стає партнером для областей України, чиї сили відбирає збройний конфлікт і наслідки пандемії. Таким чином, наступні роки принесуть довготривалі результати. Сталість цих результатів громади зможуть підтримувати та примножувати самостійно [27].

Варто зазначити, що професійними функціями фахівця із соціальної роботи мають бути: 1) допомогти тій категорії осіб, які опинилися у складних життєвих обставинах, шляхом надання соціальних послуг або заходів соціальної підтримки; 2) сприяти та визначати індивідуальні потреби особі чи сім'ї, переліку й обсягу соціальних послуг, яких потребує особа чи сім'я; 3) мінімізувати негативні наслідки складних життєвих обставин і попереджати щодо негативних явищ у суспільстві; 4) для більш детального аналізу узагальнювати інформацію щодо стану та життєвих обставин об'єкта соціальних послуг із метою визначення видів та обсягів послуг, їхнього впливу на подолання складних життєвих обставин; 5) захищати права та представляти інтереси клієнтів у різних інстанціях; 6) надавати консультації та вирішувати конфрліктні ситуації, контролювати та дотримуватись соціальних норм і гарантій; 7)·розробляти та реалізовувати соціальні програми та проєкти.

\section{ВИСНОВКИ}

Як бачимо, соціальні й економічні успіхи Німеччини це явище не тимчасове, а постійне, яке спостерігається ще $з$ перших повоєнних років. Завдяки програмі соціального забезпечення у Німеччині, особи, що потребують допомоги, можуть гідно жити, тому країна має імідж із добре функціонуючою системою соціального захисту у світі. Причому мало хто з німців на цьому спекулює, і нині рівень безробіття в країні найнижчий з часів возз'єднання Німеччини - менше п'яти відсотків. Слід наголосити, що соціальна робота $€$ важливою частиною діяльності німецької спільноти і в Україні. Основними її напрямками $є$ : оздоровлення літніх людей і осіб з обмеженими фрізичними можливостями (зокрема і дітей); адресна допомога самотнім та нужденним людям за місцем проживання, волонтерська допомога; "Зимова допомога" (продовольчі набори для самотніх і нужденних людей похилого віку, осіб з інвалідністю та багато- дітних сімей); допомога мало забезпеченим етнічним німцям медичним обладнанням; допомога студентам із соціально незахищених сімей; семінари BIZ із соціальної роботи та ін.

Таким чином, запровадження німецького досвіду в системі професійної підготовки соціальних педагогів України має сприяти всебічному розвитку професійних навичок і знань, що зможе задовольнити потреби держави у висококваліфрікованих мотивованих фрахівцях.

\section{Список використаних джерел:}

1. Сіньова Л.М. Волонтерство та соціальна робота в Україні в період карантину // Art and Science. Multilingual scientific journal. 2020, Vol. 1 (1) $100 \mathrm{c}$.

2. Сайко Н. Система професійної підготовки соціальних педагогів в Німеччині Витоки педагогічної майстерності. 2017. Випуск 19 C. $385-390$.

3. Особливості здійснення соціальної роботи в Німеччині на кінец XX - на початок XXI cт. URL: https://knowledge.allbest.ru/sociology/ 3c0a65635a2bd68a5c53b89421206c26_0.html (дата звернення 20.04.2021)

4. Heinz Dorothea. Das sozial Gesicht des Staates. Guten Tag, № 6,1991 .

5. Соціальна робота в Німеччині URL: https://moyaosvita.com.ua/ sociologiya/socialna-robota-v-nimechchini/ (дата звернення 08.06.2021)

6. Кнодель Л.В. Професійна підготовка соціальних працівників для клінічної соціальної роботи в Німеччині // Вісник Дніпропетровського Університету економіки та права імені Альфреда Нобеля Серія "Педагогіка і психологія". 2011. № 1 (1) С. 33-36

7. Лях Т.Л. Історичні засади соціально-педагогічної діяльності волонтерів за кордоном URL: https://core.ac.uk/download/pdf/19667262.pdf (дата звернення 22.06.2021)

8. Основы социальной работы: Учебник /Отв. ред. П.Д. Павленок. - М.: ИНФРА-М, 1997. - 368 с.

9. Кубіцький С.О. Технології соціально-педагогічної роботи в зарубіжних країнах: Навч. посіб. - 3-те вид. доп. і перероб. - К.: Міленіум, 2015. - 300 c.

10. Корнюшина Р.В. Зарубежный опыт социальной работы / Р.В. Корнюшина. - Владивосток: Издательство Дальневосточного университета, 2004. - 85 с.

11. Бурая Н. П. Соціальна робота : навч посібник / Н. П. Бурая. Харків : Університет внутрішніх справ, 1995. - 104 с.

12. Сіньова Л.М. Соціально-правовий захист соціальних працівників в період карантину // Тенденції розвитку науки трудового права та права соціального забезпечення: тези доповідей учасників міжнародної наук.-практ. конф. (м. Київ, 23 квітня 2021 р.) / за ред. проф. М.І. Іншина, ас. М.Б. Мельник. - Київ: "Освіта Україна", 2021. - 112 с.

13. Кизименко Л.Д., Бєдна Л.М. Словник-довідник соціального працівника URL: http://ipp.lp.edu.ua/Library/004/004.html (дата звернення 22.06.2021)

14. Соціальна робота URL: http://www.ndu.edu.ua/index.php/ua/ component/k2/item/2697-231-sotsialna-robota (дата звернення 22.06.2021)

15. Про соціальну роботу з сім'ями, дітьми та молоддю: Закон України від 21 червня 2001 року № 2558-III // Відомості Верховної Ради України (ВВР), 2001, № 42, ст.213

16. Про соціальні послуги: Закон України від 17 січня 2019 року № 2671-VIII // Відомості Верховної Ради України (ВВР), 2019, № 18, ст.73.

17. Співак Я.О. Професійна підготовка соціальних працівників із соціального захисту прав молоді: міжнародний досвід URL: http://nvd.luguniv.edu.ua/archiv/2018/N1-2(37-38)/syommd.PDF (дата звернення 22.06.2021)

18. Юрченко Д.О. Розвиток соціальної педагогіки у Німеччині URL: http://eprints.kname.edu.ua/45040/1/182-185.pdf (дата звернення 22.06.2021)

19. Bundessozialhilfegesetz in der Fassung der Bekanntmachung vom 23. Marz 1994 (BGBI. I S. 646, 2975), zuletzt geandert durch Art. 4 des Gesetzes zur Familienforderung vom 22. Dezember 1999 (BGBI. I S. 2552). URL: http://www.gesetzesweb.de/BSHG.html (дата звернення 25.06.2021)

20. Schleicher $H$ Familie und Recht: Kindschaftsrecht, Jugendhilferecht, Jugendschtrafrecht, Ehe und Scheidungsrecht / Hans Schleicher. Koln: FortisVerlag, 2003. - 459 c.

21. Ашиток Н. Професії соціальний педагог і соціальний працівник: спільне і відмінне // Людинознавчі студії. Серія "Педагогіка". Випуск С. 4-13.

22. Дужа-Задорожна М.П. Професійна підготовка соціальних педагогів до роботи з сім'єю у вищих навчальних закладах Німеччини Автореферат кандидата педагогічних наук Львівському національному університеті імені Івана Франка, Тернопіль 2014, 23 с.

23. Любецька М.М. Аналіз зарубіжного досвіду надання соціальних послуг, здійснення соціального супроводу сімей (осіб), які перебувають у складних життєвих обставинах Державне управління Iнвестиції: практика та досвід № 19/2018 C. 109-116 URL: http://www.investplan.com.ua/pdf/19_2018/24.pdf (дата звернення 29.04.2021)

24. Штрауб У. Социальная работа и связи с общественностью в Германии // Журнал исследований социальной политики. - 2002. № 5 (1). - C.75-87.

25. Палагнюк Ю.В., Письмиченко О.С. Особливості розвитку соціальних послуг у системі соціальної політики Німеччини Теорія та 
практика державного управління і місцевого самоврядування 2018 № 1 URL: http://el-zbirn-du at.ua/2018 1/20.pdf (дата звернення 22.06.2021)

26. Уряд Німеччини виділив 10 мільйонів євро на розвиток соціальних послуг і відповідь на COVID-19 у громадах на сході України URL: https://www.unicef.org/ukraine/press-releases/spilno-prolongation (дата звернення 22.06.2021)

\section{References:}

1. Sinova, L.M. (2020) Volonterstvo ta sotsial'na robota v Ukrayini v period karantynu [Volunteering and social work in Ukraine during the quarantine period]. Mystetstvo ta nauka. Bahatomovnyy naukovyy zhurnal Art and Science. Multilingual scientific journal, 1 72-85 (in Ukrainian).

2. Saiko, N. (2017) Systema profesiynoyi pidhotovky sotsial'nykh pedahohiv $v$ Nimechchyni [The system of professional training of social educators in Germany]. Vytoky pedahohichnoyi maysternosti - The origins of pedagogical skills, 19 385-390 (in Ukrainian).

3. Osoblyvosti zdiysnennya sotsial'noyi roboty $v$ Nimechchyni na kinets $\mathrm{KHKH}$ - na pochatok KHKHI st. [Features of social work in Germany at the end of the $X X$ - beginning of the XXI century] Retrieved from https://knowledge.allbest.ru/sociology/3c0a65635a2bd68a5c53b8942120 $6 \mathrm{c} 26$ 0.html (in Ukrainian).

4. Heinz Dorothea. (1991) Das sozial Gesicht des Staates [The social face of the state] Huten Teh - Guten Tag, 6 (in Germany).

5. Sotsial'na robota v Nimechchyni [Social work in Germany] Retrieved from https://moyaosvita.com.ua/sociologiya/socialna-robota-v-nimechchini/ (in Ukrainian).

6. Knodel, L.V. (2011) Profesiyna pidhotovka sotsial'nykh pratsivnykiv dlya klinichnoyi sotsial'noyi roboty v Nimechchyni [Professional training of social workers for clinical social work in Germany] Visnyk Dnipropetrovs'koho Universytetu ekonomiky ta prava imeni Al'freda Nobelya Seriya "Pedahohika i psykholohiya" - Bulletin of the Dnipropetrovsk University of Economics and Law named after Alfred Nobel Series "Pedagogy and Psychology", 1 33-36 (in Ukrainian).

7. Lyakh, T.L. Istorychni zasady sotsial'no-pedahohichnoyi diyal'nosti volonteriv za kordonom [Historical principles of social and pedagogical activity of volunteers abroad] Retrieved from https://core.ac.uk/download/ pdf/19667262.pdf (in Ukrainian).

8. Pavlenok, P.D. (1997) Osnovy sotsial'noy raboty [Fundamentals of Social Work] Moscow: INFRA-M, (in Russian).

9. Kubitsky, S.O. (2015) Tekhnolohiyi sotsial'no-pedahohichnoyi roboty $v$ zarubizhnykh krayinakh [Technologies of socio-pedagogical work in foreign countries]: Kyiv: Millennium (in Ukrainian).

10. Kornyushina, R.V. (2004) Zarubezhnyy opyt sotsial'noy raboty [Foreign experience of social work] Vladivostok: Far Eastern University Publishing House (in Russian)

11. Buraya, N.P. (1995) Sotsial'na robota [Sotsialna robota] Kharkiv: University of Internal Affairs (in Ukrainian).

12. Sinova, L.M. (2021) Sotsial'no-pravovyy zakhyst sotsial'nykh pratsivnykiv $v$ period karantynu [Socio-legal protection of social workers during quarantine] Tendentsiyi rozvytku nauky trudovoho prava ta prava sotsial'noho zabezpechennya: tezy dopovidey uchasnykiv mizhnarodnoyi nauk.-prakt. konf. Trends in the development of the science of labor law and social security law: abstracts of reports of participants in international scientific-practical. conf. (pp. 106-109) Kyiv: "Education Ukraine", (in Ukrainian).

13. Kizimenko, L.D., Bedna, L.M. Slovnyk-dovidnyk sotsial'noho pratsivnyka [Dictionary of the social worker] Retrieved from http://ipp.Ip.edu.ua/Library/004/004.html (in Ukrainian).

14. Sotsial'na robota [Social work] Retrieved from http://www.ndu.edu.ua/ index.php/en/component/k2/item/2697-231-sotsialna-robota (in Ukrainian).

15. Pro sotsial'nu robotu z sim'yamy, dit'my ta moloddyu: Zakon Ukrayiny [On social work with families, children and youth] № 2558-III-VR
(2001). Vidomosti Verkhovnoyi Rady Ukrayiny [Bulletin of the Verkhovna Rada of Ukraine] (VVR), (42) 213 (in Ukrainian).

16. Pro sotsial'ni posluhy: Zakon Ukrayiny [On social services] № 2671-VIII-VR (2019). Vidomosti Verkhovnoyi Rady Ukrayiny [Bulletin of the Verkhovna Rada of Ukraine] (VVR), (18) 73 (in Ukrainian).

17. Singer, Ya.O. Profesiyna pidhotovka sotsial'nykh pratsivnykiv iz sotsial'noho zakhystu prav molodi: mizhnarodnyy dosvid [Training of social workers in the social protection of youth rights: international experience] Retrieved from http://nvd.luguniv.edu.ua/archiv/2018/N1-2(37-38)/syommd.PDF (in Ukrainian).

18. Yurchenko, D.O. Rozvytok sotsial'noyi pedahohiky u Nimechchyni [Development of social pedagogy in Germany] Retrieved from http://eprints.kname.edu.ua/45040/1/182-185.pdf (in Ukrainian).

19. Federal'nyy zakon pro sotsial'ne zabezpechennya [Federal Social Welfare Act in the version] published on March 23, (1994) Federal'nyy visnyk zakonu (Federal Law Gazette I p. 646, 2975), last amended by Art. 4 of the Law on Family Support of December 22, 1999 (Federal Law Gazette I p. 2552). Retrieved from http://www.gesetzesweb.de/BSHG.html (in Germany).

20. Schleicher, H. (2003) Sim'ya ta pravo: pravo dytynstva, pravo dobrobutu molodi, kryminal'ne pravo molodi, pravo shlyubu ta rozluchennya [Family and Law: Childhood Law, Youth Welfare Law, Youth Criminal Law, Marriage and Divorce Law] Koln: Fortis Verlag, (in Germany).

21. Ashitok. N. Profesiyi sotsial'nyy pedahoh i sotsial'nyy pratsivnyk: spil'ne i vidminne [Professions social pedagogue and social worker: common and different] Lyudynoznavchi studiyi. Seriya "Pedahohika". [Anthropological Studies. Series "Pedagogy"]. 4-13 (in Ukrainian).

22. Duzha-Zadorozhna, M.P. (2014) Profesiyna pidhotovka sotsial'nykh pedahohiv do roboty $z$ sim"yeyu u vyshchykh navchal'nykh zakladakh Nimechchyny [Professional training of social pedagogues to work with the family in higher educational institutions of Germany] Abstract of the Candidate of Pedagogical Sciences L'vivs'komu natsional'nomu universyteti imeni Ivana Franka [at Ivan Franko National University of Lviv], Ternopil (in Ukrainian).

23. Lyubetska, M.M. (2018) Analiz zarubizhnoho dosvidu nadannya sotsial'nykh posluh, zdiysnennya sotsial'noho suprovodu simey (osib), yaki perebuvayut' u skladnykh zhyttyevykh obstavynakh [Analysis of foreign experience in providing social services, providing social support to families (persons) in difficult life circumstances] Derzhavne upravlinnya Investytsiyi: praktyka ta dosvid [Public Administration Investments: practice and experience] 19 109-116 Retrieved from http://www.investplan.com.ua /pdf/19 2018/24.pdf (in Ukrainian).

24. Straub, W. (2002) Sotsial'na robota ta zv'yazky z hromads'kistyu v Nimechchyni [Social work and public relations in Germany] Zhurnal doslidzhen' sotsial'noyi polityky [Journal of Social Policy Research]. 5 (1). 75 -87 (in Russian).

25. Palagniuk, Yu.V., Pismichenko, O.S. (2018) Osoblyvosti rozvytku sotsial'nykh posluh u systemi sotsial'noyi polityky Nimechchyny [Features of the development of social services in the social policy system of Germany] Teoriya ta praktyka derzhavnoho upravlinnya $i$ mistsevoho samovryaduvannya [Theory and practice of public administration and local self-government] 1 Retrieved from http://el-zbirn-du.at.ua/2018_1/20.pdf (in Ukrainian).

26. Uryad Nimechchyny vydilyv 10 mil'yoniv yevro na rozvytok sotsial'nykh posluh i vidpovid' na COVID-19 u hromadakh na skhodi Ukrayiny [The German government has allocated 10 million euros for the development of social services and the response to COVID-19 in communities in eastern Ukraine] Retrieved from https://www.unicef.org/ ukraine/press-releases/spilno-prolongation (in Ukrainian).

Received: $27 / 06 / 2021$ Accepted: $20 / 11 / 2021$

L. Sinova, PhD (Law), Associate Prof.

Taras Shevchenko National University of Kyiv, Kyiv, Ukraine

\section{ORIGINATION AND DEVELOPMENT OF SOCIAL WORK IN GERMANY}

The article examines the features of the historical development of social work in Germany. In the XIX century where the health of German citizens was seen more than a social value. By the middle of the XX century. Anglo-American methods of social work, which are still considered classical, became widespread in Germany. Most schools of social work were founded by the church and gave women a clearly defined mission within ideological and social goals, as women were seen as a natural and traditional embodiment of charity. In the 1970s, there was a rethinking of social work in Germany due to the fact that scientists and practitioners concluded that the use of classical methods of social work was insufficient, as well as the use of therapeutic tools in cases of coverage and solution in were generally seen as insufficient. In the scientific world of Germany there were discussions about the benefits of systemic approaches in social work.

Today, the mission of social work is to enable people to maximize their potential, enrich their lives and prevent dysfunction. Professional social work is aimed at protecting people, solving their problems and social transformations in society.

The development of social pedagogy as a science and an independent branch of knowledge and practical activity of social work in Germany is studied. Thus, for the successful development of the system of professional training of social workers in social protection of rights in Ukraine, young professionals need to research and use international experience. The introduction of the German experience in the system of professional training of social pedagogues of Ukraine will help meet the needs of the state in highly qualified motivated specialists.

Keywords: poverty, charity, life circumstances, social security, social worker, social pedagogue, social assistance, social services. 
Bulletin of Taras Shevchenko National University of Kyiv. Legal Studies, 2021; 4 (119): 97-101 УДК 343.163

DOI: https:doi.org/10.17721/1728-2195/2021/4.119-19
ISSN $1728-2195$

(C) Taras Shevchenko National University of Kyiv, Publishing center "Kyiv University", 2021

М. М. Стефранчук, д-р юрид. наук, доц. ORCID ID: 0000-0002-6239-9091

Київський національний університет імені Тараса Шевченка, Київ, Україна

\section{ЗВІЛЬНЕННЯ ПРОКУРОРІВ ПІД ЧАС АТЕСТАЦІЇ: ВИЗНАЧЕННЯ ПІДСТАВ}

Висвітлено проблемні аспекти практичної реалізації положень законодавства, яким регламентовано процедуру звільнення прокурорів із посади під час атестації, у частині визначення підстав для такого звільнення.

Метою наукової статmі визначено виявлення проблемних аспектів законодавчої регламентації підстав для звільнення прокурорів під час атестації, судової практики застосування цього законодавства та формулювання пропозицій щодо їхнього врегулювання.

Установлено, що сучасний етап реформування прокуратури в Україні втілено у першочергових заходах із рефоормування органів прокуратури, які безпосередньо торкнулися таких гарантій незалежності прокурора, як особливий порядок його призначення на посаду та звільнення з посади. Констатовано, що недоліки законодавства у частині закріплення процедури атестації прокурорів сформували поширену практику оскарження результатів проведеної атестації в суді звільненими прокурорами.

Проаналізовано судову практику у сфері вирішення спорів щодо звільнення прокурорів під час атестації, яка свідчить про відсутність єдиної та одноманітної позиції судів при вирішенні цієї категорії справ.

Аргументовано, що відсутність єдиної та одноманітної судової практики вирішення спорів щодо звільнення прокурорів під час атестації є свідченням невідповідності законодавства, яким регламентовано особливості звільнення прокурорів із посад під час атестації, принципу правової визначеності, як одному з елементів верховенства права, за змістом якого юридичні норми мають бути чіткими і точними, забезпечувати стан їхнього однакового застосування й виключати необмеженість їхнього трактування у правозастосовній практиці.

Запропоновано для обґрунтованого визначення підстав для звільнення прокурорів під час атестації застосовувати способи тлумачення відповідних правових норм з урахуванням вимог принципу правової визначеності та критерію "якість закону", як складової принципу верховенства права та гарантії застосування судом найбільш сприятливого для особи способу тлумачення закону.

Ключові слова: реформа прокуратури, атестація прокурорів, підстави для звільнення прокурорів, правова визначеність, "якість закону".

\section{ВСТУп}

Законом України "Про прокуратуру" від 14 жовтня 2014 р. № 1697-VII (далі Закон № 1697-VII) серед гарантій незалежності прокурора закріплено, поміж інших, особливий порядок його призначення на посаду та звільнення з посади, а також визначено, що прокурор призначається на посаду безстроково та може бути звільнений із посади, його повноваження на посаді можуть бути припинені лише з підстав і в порядку, передбачених законом (ст. 16).

Показово, що у редакції Закону № 1697-VII, до внесення змін до нього Законом України "Про внесення змін до деяких законодавчих актів України щодо першочергових заходів із реформи органів прокуратури" від 19 вересня 2019 р. № 113-IX (далі - Закон № 113-IX) [1], прокурор міг бути звільнений із посади, його повноваження на посаді могли бути припинені лише з підстав і порядку, передбачених виключно Законом № 1697-VII.

Отже, вказані заходи з реформи органів прокуратури призвели до певного звуження гарантій незалежності прокурора, які були закріплені у Законі № 1697-VII як втілення європейських стандартів організації та діяльності прокуратури. Так, у Звіті Венеціанської комісії 3 Європейських стандартів щодо незалежності судової системи: ч. II - Служба обвинувачення, ухваленому на 85-му пленарному засіданні (Венеція, 17-18 грудня 2010 р.) [2], зазначено, що якості, які вимагаються від обвинувача, подібні до якостей судді та потребують наявності відповідних процедур призначення та просування по службі. Із цих причин необхідно забезпечити належний термін перебування на посаді та відповідні заходи щодо просування по службі, дисциплінарних заходів і звільнення, що забезпечить неможливість переслідування обвинувача на підставі того, що він прийняв непопулярне рішення (п. 18). Аби уникнути неправомірних вказівок, необхідно розробити каталог гарантій невтручання у діяльність обвинувача. Такі гарантії повинні охоплювати призначення, дисциплінарні заходи/усунення з посади, а також специфічні правила ведення справ і процесу прийняття рішень (п. 32). Обвинувачі мають перебувати на посаді аж до виходу на пенсію, оскільки призначення на лімітовані періоди 3 можливістю перепризначення містять ризик того, що обвинувач буде приймати рішення не на основі закону, але з думкою зробити приємне тому, хто його чи іï перепризначатиме (п. 50).

Першочергові заходи з реформи органів прокуратури, запроваджені Законом № 113-IX, безпосередньо торкнулися таких гарантій незалежності прокурора, як особливий порядок його призначення на посаду та звільнення з посади, та стали предметом численних судових позовів. Ба більше, вони $є$ предметом конституційного подання щодо їхньої відповідності Конституції України, у якому суб'єкт права на конституційне подання обстоює позицію, що прийняття оспорюваного Закону обумовило звуження змісту й обсягу існуючих прав громадян, запровадило дуалізм правових засад організації і діяльності прокуратури України, статусу прокурорів [3].

У експертному науковому середовищі також піддають критиці законодавчі зміни у досліджуваній сфері, за якими відбулося звуження змісту й обсягу існуючих гарантій трудових прав прокурорів, попри пряму заборону таких дій у ст. 22 Конституції України [4, с. 151], а також стверджується, що недоліки процедури проведення атестації прокурорів створюють передумови для незаконних і необґрунтованих рішень щодо звільнення прокурорів з обійманих ними посад, та про неможливість поновлених за рішеннями судів прокурорів відновити свої трудові права через прогалини і колізії у законодавстві [5, с. 583].

Попри те, що на розв'язання деяких з означених проблем спрямовані зміни, внесені до Закону № 113-ІХ Законом України від 15 червня 2021 р. № 1554-ІХ "Про внесення змін до розд. II "Прикінцеві і перехідні положення" Закону України "Про внесення змін до деяких законодав- 